\title{
Formation of hypotheses of redevelopment of cultural heritage objects of the residential complex "Krasny Vyborzhets"
}

\author{
Anastasiia Savchuk ${ }^{*}$ and Irina Ptukhina \\ Peter the Great St.Petersburg Polytechnic University, Polytechnicheskaya, 29, St.Petersburg, 195251, \\ Russia
}

\begin{abstract}
Subject of study: issue of redevelopment of industrial zones that have lost its purpose, which have a huge potential for renovation in the current conditions of development of a modern metropolis. Based on the example of a housing complex projected on the territory of the «Krasny Vyborzhets» factory the article describes approaches to the renovation of historical buildings located on the territory of the future residential complex, which cannot be demolished due to town planning regulations. Objectives: the formation of the hypotheses of redevelopment of cultural heritage objects belonging to the residential complex being designed on the territory of the plant "Krasny Vyborzhets". Materials and methods: mapping methods, SWOT analysis, world experience of redevelopment were used. Results: the main direction of redevelopment was chosen to create a cultural and business center "Rosenkrantz" with a modern open public space, which is based on the combination of three historical eras. Conclusions: this type of redevelopment will increase the security of this area, the attractiveness of the residential complex for future costumers of apartments and also will create a public space for leisure activities for local residents and their children.
\end{abstract}

\section{Introduction}

Renovation of industrial areas of developing megacities is an urgent problem of urban planning, the process of which involves a large number of interested parties: from executive authorities to ordinary residents. With the development of science-intensive and innovative production, the city gradually turns into an administrative and business center, and, accordingly, the administrative and office quarters become the semantic dominants of cities, highrise buildings appear, etc. Previously, the dominant industrial zones are disrupted and suppressed by modern buildings. Technologies are moving forward, old methods of production become obsolete, many enterprises, because of inefficient production and obsolescence, stop their work and, as a result, are gaps in the urban planning system of modern cities. To date, many industrial facilities are cut off from the urban social environment, the city does not benefit from the use of land in the industrial belt, so these territories are not involved in the functioning of the city, which negatively affects the sustainable development of mega-

\footnotetext{
*Corresponding author: savchuk-anastacia@yandex.ru
} 
cities around the world. To date, there are several types of renovation areas of industrial zones, namely: the preservation of the industrial load of the facility, the partial re- functionalization and the full re-functionalization.

Fortunately, the history of world urban development knows many examples of successful implementation of redevelopment projects of inactive industrial enterprises. For example, popular examples of Russian and world practice of qualitative transformation of industrial areas, such as Hafen City in Hamburg, the Docklands district in London, the Pacific park in Amsterdam, the High Line Park in New York, the shopping and entertainment center "Manufactura" in the city of Lozd, quarter Wine House in Moscow.

Redevelopment of industrial facilities is a very important step towards the development of a modern city, such projects are commercially viable and attractive to a potential buyer, but at the same time the process of developing such zones by the developer causes considerable legal difficulties associated with regulatory regulation that may affect the timing of construction.

This article will describe the study of the optimal ways to renovation of three buildings which are objects of cultural heritage, and are part of the residential complex that is being designed on the territory of the Krasny Vyborzhets factory.

\section{Literature review}

In the book of N. P. Shepelev, M.S. Shumilov. "Reconstruction of urban development" outlines the features of the old buildings and engineering surveys conducted during its reconstruction. The principles of planning and engineering improvement of territories, sanitation and gardening, organization of movement and social and consumer services are covered. Methods of protection from dangerous natural processes are considered, the methods of modernization of residential apartments, repair and reconstruction of buildings are given.

E.A. Karaulova in her article "Redevelopment as a method of modifying" the failures "of urban planning fabric" describes the process of secondary, as a rule, complex development of individual real estate objects, groups of buildings or territories; their re-profiling into completely new objects, often with a change in functional purpose, with the purpose of their most effective use.

\section{Materials and methods}

\subsection{Case of research and initial data}

The Vyborg side was historically formed as an industrial suburb of St. Petersburg. In the times of the famous "construction boom" of the beginning of the 20th century, when new streets and avenues were being drawn up on the Petrograd side, factory buildings and factories were being built in Vyborgskaya.

Today, after a century, after the gradual withdrawal of the production facilities of the Vyborg side, it became possible to develop this important part of the city in the traditional way for St. Petersburg urban development, with the creation of ceremonial squares, boulevards and embankments.

The plot under the projected residential complex is located in the block bounded by the Sverdlovskaya embankment and Vatutin, Mineralnaya and Arsenalnaya streets. Through the quarter from the south-west to the north-east passes Kondratievsky prospect. The territory planned to be built up to the present time is occupied by the buildings of the Krasny Vyborzhets factory. In their place is planned to build 157 thousand square meters of housing, houses will have 6-9 floors in height. The first floors of the buildings will be given commerce. The construction company intends to begin construction of the facility in the period from the end of 2018 to the beginning of 2019. 
The developer also plans to create his own infrastructure. Inside the block there should be a school for 825 places and a kindergarten for 380 children. For car owners are planned underground parking lots in total designed for 2.4 thousand cars. [1]

From the metro station "Ploshchad Lenina" to the projected residential quarter can be reached on foot, the distance is $1.5 \mathrm{~km}$. Buses and trolleybuses run from several metro stations, including Lenin Square, Akademicheskaya, Pionerskaya, Sportivnaya, Vasileostrovskaya, Baltiyskaya, Technologicheskiy Institut and others. By car, the way from the city center should take about 10 minutes.

New residential complex there is practically in the heart of the industrial zone: to the east is the Leningrad Metal Plant, west - Machine-Building Factory "Arsenal", to the south - Machine-building plant "Fenix", to the north - trolleybus depot. In the western part of the block, in which the complex is planned to be built, a pre-trial detention center and a psychiatric hospital are currently located. There is very little greenery around - the Sverdlovsk Gardens are located in the southern part of the quarter, and the Neva River flows along the south-eastern border.

Since this is a former industrial area, the infrastructure is not there. The nearest school is $1 \mathrm{~km}$ in a straight line to the northeast on Zhukov Street, a kindergarten - 850 meters straight to the south-west. Several hundred meters to the west there is a polyclinic, near the metro station "Ploshchad Lenina" there are the Military Medical Academy and the Children's Clinical Hospital. The nearest shopping centers near the metro station "Ploshchad Lenina" and at the intersection of Kondratyevsky and Polyustrovsky avenues.

The object of the research was a territory with a square and three buildings of different historical epochs, being objects of cultural heritage and having, in this connection, a number of corresponding restrictions. In accordance with the project, the facilities are part of the new residential quarter, and during the research it was necessary to determine the functional purpose of these buildings, taking into account the features of not only the existing but also the developing environment.

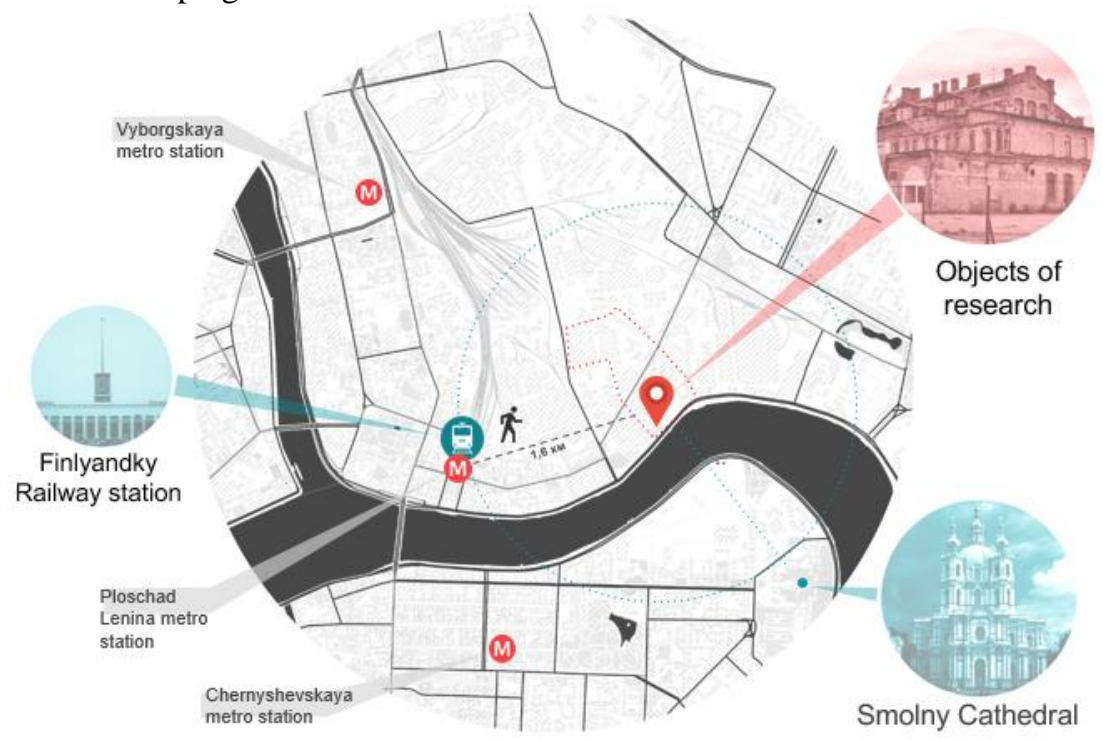

Fig. 1. Location of objects

The objects of the research were: the production and service building, the culture house and the stewards's house (Figure 2). At the moment the buildings are in poor condition and unsuitable for use. 


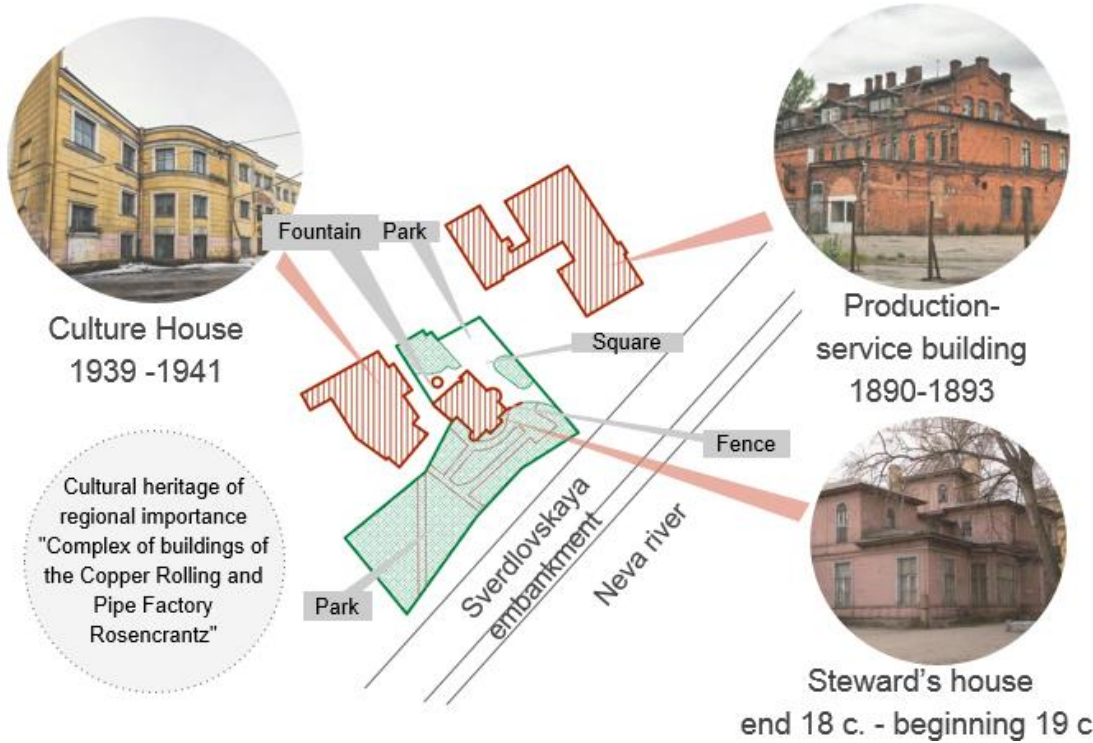

Fig. 2. Objects of research

\section{Legal restrictions}

These buildings belong to the objects of cultural heritage of regional importance "Complex of buildings of the Copper Rolling and Pipe Plant Rosencrantz." The complete scheme of the location of protected objects, provided by the Committee of Property Relations, is shown on Figure 3.

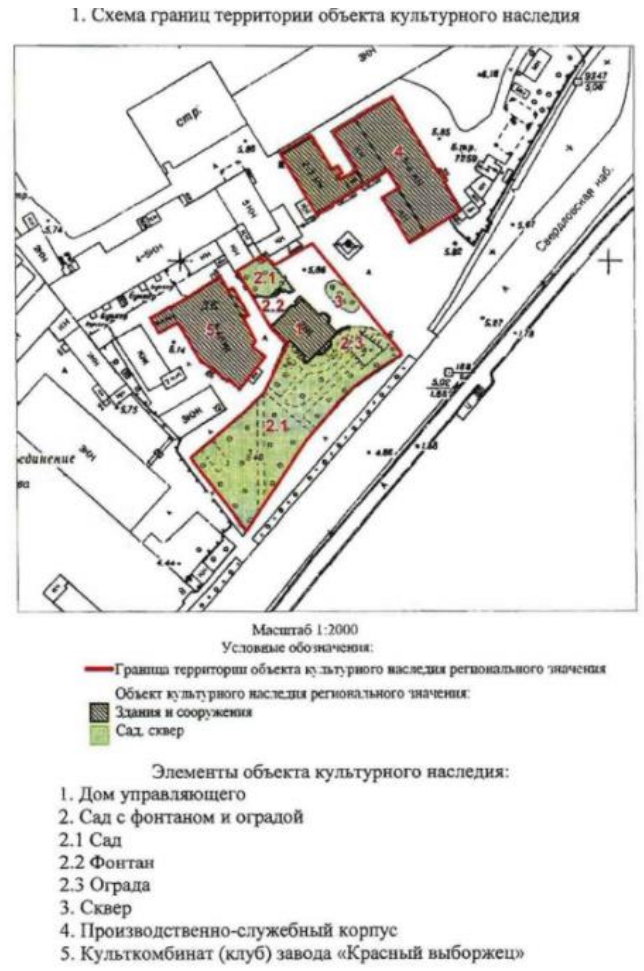

Fig. 3. Scheme of location of objects of cultural heritage 
The restrictions imposed on these facilities in accordance with the legislation of St. Petersburg are given in Table 1.

Table 1. Restrictions on case objects

\begin{tabular}{|l|l|}
\hline \multicolumn{1}{|c|}{ Object } & \multicolumn{1}{|c|}{ Under protection } \\
\hline Steward's house & $\begin{array}{l}\text {-volume-spatial solution (location, historical dimensions and con- } \\
\text { figuration in plan); } \\
\text {-constructive building system (load-bearing structures, cantilever } \\
\text { design of choruses, configuration of arches, fencing of stairs, bal- } \\
\text { conies, configuration and dimensions of window and door open- } \\
\text { ings); } \\
\text { - decorative and artistic decoration of the interiors (fencing and } \\
\text { filing of staircases, fencing of the choir gallery, colored stained- } \\
\text { glass windows, decorative finishing of ceilings (power sockets, } \\
\text { panels, false sails, stucco molding), finishing the room: oak ceiling, } \\
\text { finishing the lower part of the walls with oak panels. }\end{array}$ \\
\hline Production and service complex & $\begin{array}{l}\text {-a spatial-spatial solution (location, historical dimensions and con- } \\
\text { figuration in terms of, marks of pipes, skates, roofing material) } \\
\text {-constructive building system (external and internal bearing walls, } \\
\text { overlapping marks, floors, historical building frame, ladders (di- } \\
\text { mensions, configuration, construction), metal fences of staircases, } \\
\text { construction of tape glazing, historical lintels of window and door } \\
\text { openings) } \\
\text { - architectural and artistic solution, composition of facades (win- } \\
\text { dow, doorways, external facade decoration) } \\
\text { memorial plaques, monuments (the honorary board of 1936, the } \\
\text { memorial to the participants of the Second World War, the monu- } \\
\text { ment-stella to the young red-roders) }\end{array}$ \\
\hline House of Culture & $\begin{array}{l}\text {-a spatial-spatial solution (location, historical dimensions and con- } \\
\text { figuration in plan) } \\
\text {-constructive building system (external and internal load-bearing } \\
\text { structures, spiral staircase) } \\
- \text { architectural and artistic solution, composition of facades (materi- } \\
\text { al and character of facades, configuration, dimensions of door and } \\
\text { window openings) } \\
\text { - decorative and artistic decoration of the interiors (decorative and } \\
\text { stucco decoration of walls and ceiling, arches of the second light, } \\
\text { arched niches, plafonds, rosettes and caissons, decorative flooring, } \\
\text { doorways with filling) [2] }\end{array}$ \\
\hline
\end{tabular}

\subsection{Methods of research}

Mapping method - the method of fixing the location of the various features of social facilities in the territory of the municipal district, municipality, village by social security cards.[3]

In this case, the area of the study was the territory, located about 6 kilometers from the residential complex. In this territory are identified all the features of the terrain, existing facilities, their condition, the overwhelming type of people who stay in the immediate vicinity of the future residential complex, held "short interviews" with people. Also, three points were chosen for measuring social scenarios at different times of the day, on weekdays and weekends. 


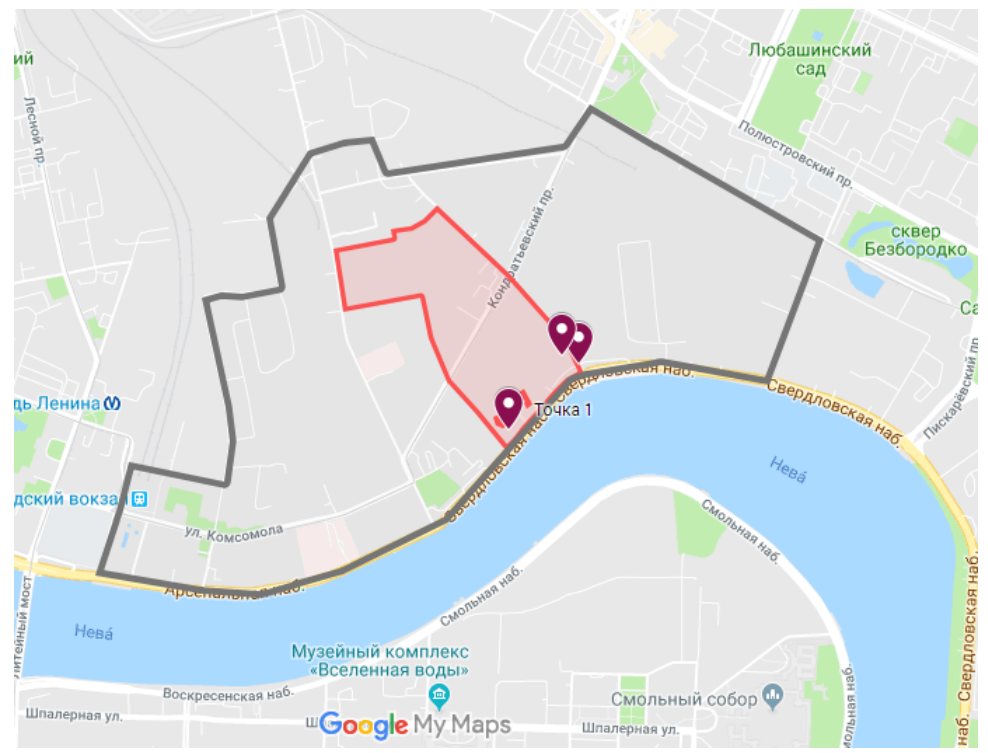

Fig. 4. Area of case research by mapping method

The results of the measurements showed that the overwhelming social types are office workers (45\%), students (14\%) and sportsmen (9\%), Figure 5. Social scenarios for each point were different, despite their proximity to each other: for points 1 and 2 it was office workers, but for point 3 it was the local residents of the area. "Short interviews" showed that people living and working in this area do not consider this area attractive for leisure activities, children are afraid to walk alone in the evening. Thus, at least one of the buildings under investigation needs to be transformed into a place of recreation, which will increase the level of security, and people will not have to spend time on a trip to the city center to spend their free time.

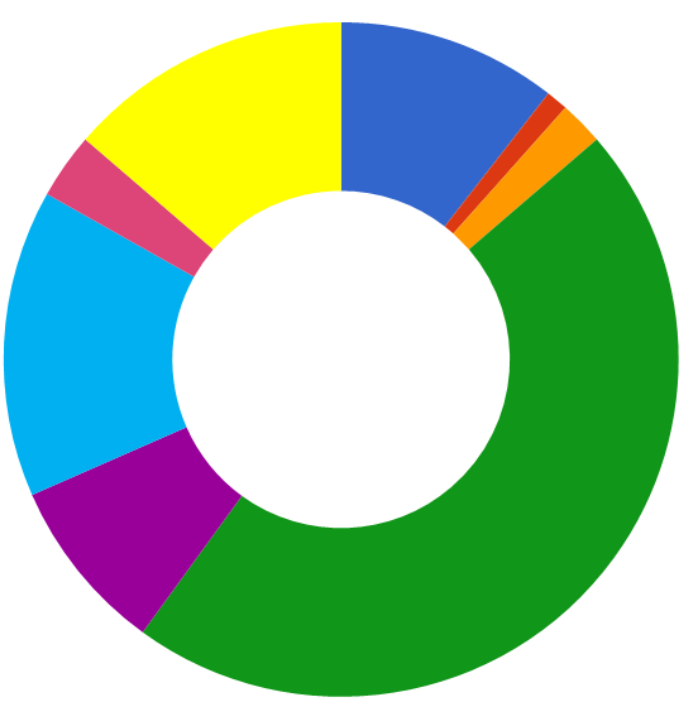

Sportsmen

- Military workers

Dogs owners

- Office workers

- Ordinary passers-by

- Factory workers

- Parents with kids

Students

Fig. 5. Social archetypes of the area 


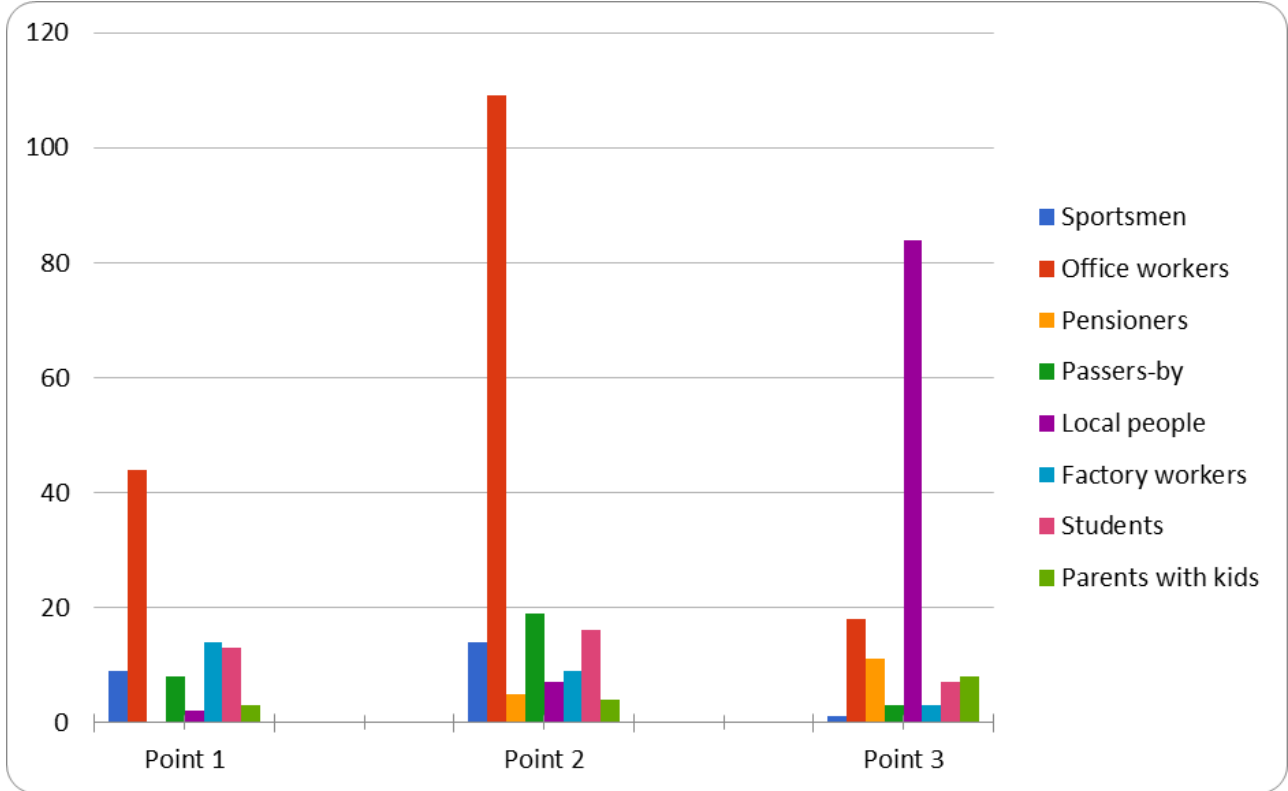

Fig. 6. Social indicators of each point

\subsection{SWOT analysis}

Territorial marketing is a specialized marketing activity undertaken on the territory with the purpose of creating, maintaining or changing about it the opinions, intentions and / or behavior of subjects, both existing and existing in the territory, and potential. SWOT analysis in territorial marketing acts as a tool for strategic planning. [4]

Based on the "field" studies of the terrain and study of town planning regulations, a SWOT matrix of strengths and weaknesses of this territory was formed, Table 2.

Table 2. SWOT-analysis of the territory

\begin{tabular}{|c|c|}
\hline $\mathrm{S}$ - Strengths & W - Weaknesses \\
\hline $\begin{array}{l}\text { 1. Proximity of the center - devel- } \\
\text { oped infrastructure } \\
\text { 2. Objects of cultural heritage, } \\
\text { historical buildings } \\
\text { 3. View of the historical center } \\
\text { 4. developed transport infrastruc- } \\
\text { ture } \\
\text { 5. Bright cultural code } \\
\text { 6. developed social infrastructure }\end{array}$ & $\begin{array}{l}\text { 1. The proximity of the motorway on the Sverd- } \\
\text { lovskaya embankment } \\
\text { 2. large number of industrial zones - closed areas, } \\
\text { without general access } \\
\text { 3. The prevailing number of people working, but not } \\
\text { living on the territory } \\
\text { 4. Objects of cultural heritage, historical buildings } \\
\text { 5. small area of greenery of streets } \\
\text { 6. The lack of comfortable open (on the street) com- } \\
\text { monly. Space and recreational areas in walking dis- } \\
\text { tance } \\
\text { 7. ecological situation - contamination of soil and air } \\
\text { 8. Neighborhood with psychiatric hospital and SIZO } \\
\text { 9. lack of comfortable walking routes between pl. } \\
\text { Lenin - Red Vyborzhets - Polustrovo, can lead to the } \\
\text { isolation and closeness of the new residential complex } \\
\text { and the objects under consideration }\end{array}$ \\
\hline
\end{tabular}




\begin{tabular}{|c|c|}
\hline $\mathrm{O}$ - Opportunities & $\mathrm{T}$ - Threats \\
\hline $\begin{array}{l}\text { 1. proximity of the river } \\
\text { 2. The proximity of the station - a } \\
\text { major transport junction, a point } \\
\text { of attraction } \\
\text { 3. large flow total. transport from } \\
\text { the square. Lenin in Polustrovo } \\
\text { through the territory under con- } \\
\text { sideration } \\
\text { 4. The prevailing number of peo- } \\
\text { ple working, but not resident in } \\
\text { the territory } \\
\text { 5. Construction of a bridge in the } \\
\text { alignment of Arsenalnaya street } \\
\text { 6. The likelihood of transferring } \\
\text { industrial zones to other catego- } \\
\text { ries of use - residential and busi- } \\
\text { ness } \\
\text { 7. existing points of activity - a } \\
\text { single development of the area } \\
\text { 8. pedestrian embankment - pe- } \\
\text { destrians, cyclists, roller skaters in } \\
\text { the summer } \\
\text { 9. The proximity of water routes } \\
\text { in the warm season }\end{array}$ & $\begin{array}{l}\text { 1. a large flow of public transport from the square. } \\
\text { Lenin in Polustrovo through the territory under con- } \\
\text { sideration - aggravation of the transport situation } \\
\text { 2. small area of greening the streets } \\
\text { 3. existing points of activity - competitors } \\
\text { 4. Neighborhood with psychiatric hospital and SIZO } \\
\text { 5. lack of comfortable walking routes between sq. } \\
\text { Lenin - Red Vyborzhets - Polustrovo, can lead to iso- } \\
\text { lation and closeness of the new residential complex } \\
\text { and the objects under consideration }\end{array}$ \\
\hline
\end{tabular}

\section{Results}

Based on the study of the regulatory framework corresponding to these renovation objects, the study of social scenarios of the area and the research of a SWOT analysis of the territory, hypotheses of redevelopment of three historic buildings included in the residential complex on the territory of an industrial enterprise were revealed. The main direction of redevelopment was chosen to create a cultural and business center "Rosenkrantz" with a modern open public space, which is based on the combination of three historical eras.

Thus, three functional schemes for each of the objects were designed:

1) The Soviet era - a zone belonging to the house of culture. There is supposed the location of the restaurant, a small concert hall and unique circles for children on the first and second floors, the functional scheme is presented in Figure 7. 


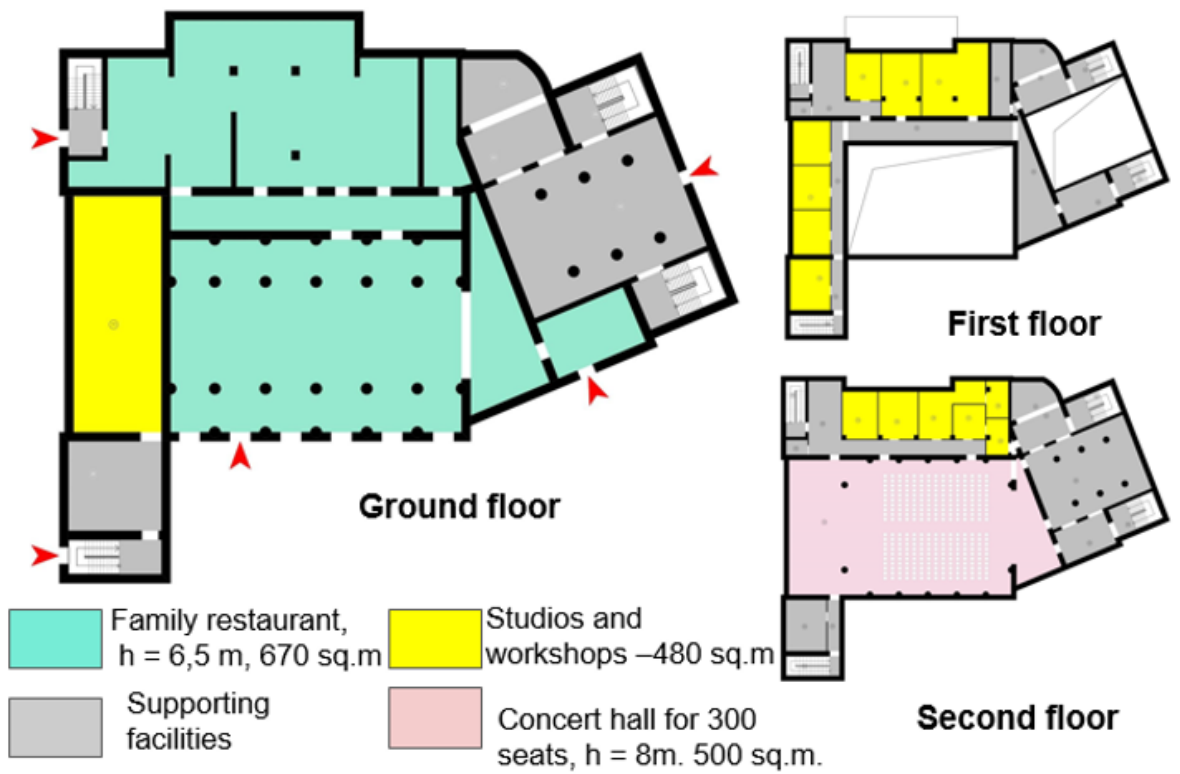

Fig. 7. Functional plan for renovation of the Culture House

2) The era of industrialization - the territory of the Production Complex- will be able to unite the industrial museum on the ground floor, and the first floor can be occupied by the office of IT or an industrial company, Figure 8.

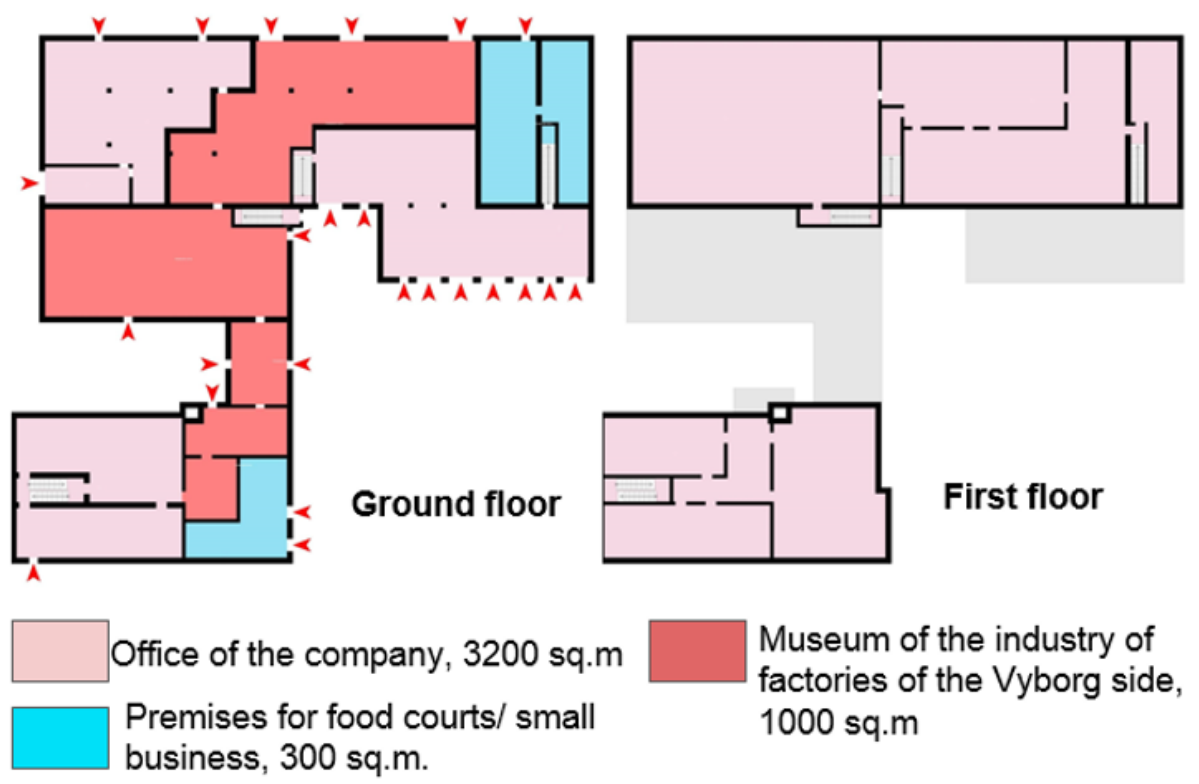

Fig. 8. Functional plan for renovation of the Production Complex

3) "Russian Homestead" - will be located in the Steward's House and is a coworking place for public events, a small cafe on the ground floor and the office of the managing company of the residential complex under construction on the first floor, Figure 9. 

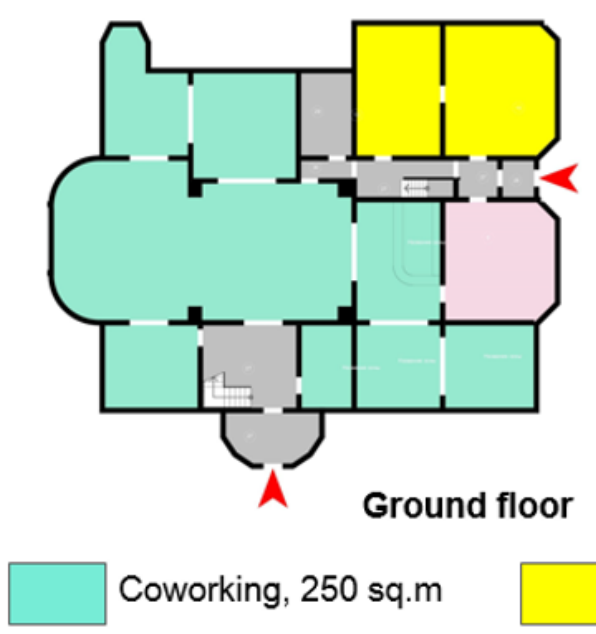

Coworking, 250 sq.m

Technical rooms for coworking, coffee houses

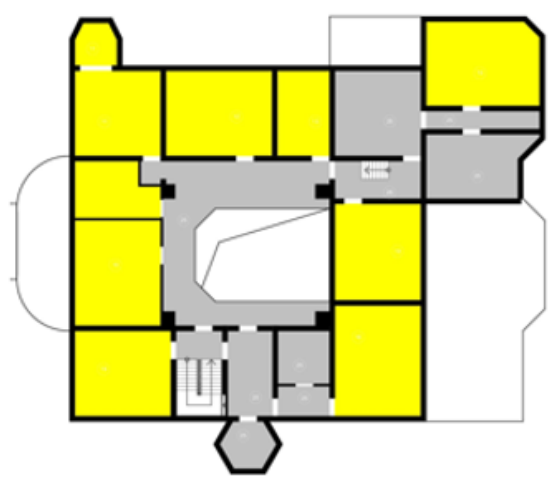

First floor

The management company housing complex, and cultural and leisure center, 240 sq.m.

Supporting facilities

Fig. 9. Functional plan for redevelopment of Steward's House

\section{Conclusion}

The chosen way of redevelopment of the investigated objects of cultural heritage located on the territory of the former industrial enterprise will bring economic benefit to both the developer as for investor and for the city, as it will lead to a large number of large tenants. Also, this concept will increase the attractiveness of the residential complex under construction for potential buyers, as it distinguishes it from the projects of other developers. In addition, the development of this hypothesis will lead to an increase in the public spaces of the area for leisure activities without loss of time for a trip to the city center and will increase the overall security of the area, and the appearance of the office of a large company in one of the buildings will change the image of the region for the better.

\section{References}

1. Official site of new buildings of St. Petersburg [electronic resource] https://www.novostroy.su/buildings/krasnyy-vyborzhets/ (reference date: 22.09.2018);

2. Federal Law of June 25, 2002 N 73-FZ "On Objects of Cultural Heritage (Monuments of History and Culture) of the Peoples of the Russian Federation";

3. J.Nichols Maps and Meanings: Urban Cartofraphy and Urban Design, The Univesity of Adelaide, 2012, 12 p.

4. Hakimeh Khalifipour, Alireza Soffianaian, Sima Fakheran Application of SWOT Analysis in Strategic Environmental Planning: A CaseSstudy of Isfahan/ Iran, International Conference on Applied Life Sciences (ICALS2012), 10-12 September 2012, Turkey.

5. A. Chan, E. Cheung, I. Wong, Revitalizing industrial buildings in Hong Kong-a Case Review, Sustainable Cities and Society 15 (2015) 57-63.

6. N.P. Shepelev, M.S. Shumilov. Reconstruction of urban development. Moscow: Higher School, 2000. -271 p. 